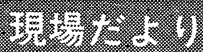

\section{財団法人 リモートセンシング技術センター}

（財）リモートセンシング技術センター 丸 尾 啓 二

\section{1. はじめに}

財団法人リモートセンシング技術センターは，「地球 の資源抢よび現象等について探査するリモート・センシ ングに関する研究開発を行い，その成果を普及し，むっ て社会経済の発展，環境の保全および国民の福社向上に 寄与する」てとを目的として昭和 50 年 7 月三井物産, 三菱商事両社の援助と科学技術庁および宇宙開発事業団 の指導のむとに設立され，リモート・センシング技術に 関する調査・研究，リモート・センシング・データの収 集抢よび配布，リモート・センシングに関する人材の養 成，リモート・センシングに関する普及㤵発，リモート・ センシングに関する国際協力などの事業を行っている.

財団の組織は，理事長鈴江康平の下に専務理事松友信 寿, 常務理事宮崎健吉の常勤理事 2 名がおり, 専務理事 が事務局長を兼務している. 企画部は技術的業務に関す る企画業務, 調査部はリモート・センシング技術に関す る調查・文献の收集・人材の養成・普及啓発, 研究部は リモート・センシング・データの解析研究・解析手法に 関する研究，技術部は宇宙開発事業団地球観測センター におけるデータの処理および提供に関する協力データの 収集配布などを行っている.

\section{2. 各部 の 活 躍}

昭和 54 年度に行った事業の概要を説明する.

\section{1. 企画 ・調查部}

（1）科学技術庁から受託の「低コスト解析技術の開発 研究」

ての調查は従来リモート・センシング・データを解 析する装置が高価で, また, 多額の運用コストがかか っている点を解消するため, さらに今後のリモートセ ンシングの発展を図るため, 低コストで運用費の安い 装置を開発するための研究で, 昭和 53 年度に引続き 行ったものである.

（2）科学技術庁から受託の「陸域観測衛星技術の開発 に関する調査」

昭和 53 年に宇宙開発委員会に㧍いて策定された宇
宙開発政策大綱に基づく「海域および陸域観測衛星 (MOS・LOS) シリーズ」の陸域観測衛星システムの 開発整備に関する調查研究であり, 通産省が計画中の 資源探查衛星構想と一本化して昭和 61 年度頃に「地 球資源衛星 ERS-1」として打上げが計画されている.

（3）宇宙開発事業団から受託の「アクティブ・マィク ロ波センサーのシステム解析評価」

昭和 59 年度に打上げられる予定の海洋観測衛星 1 号 (MOS-1) に引続き, 海洋観測衛星 2 号 (MOS-2) の打上げが検討されているが，ての調查研究はMOS2 の主要ミッション機器に予定されているマイクロ波 センサーのうちの, アクティブマイクロ波センサー (散乱計, 高度計)システムに対する要求条件の設定, 処理アルゴリズムの明確化を行い, アクティブ・マイ クロ波センサーの開発および支援サブシステムの開発 のための基礎資料を得ることを目的としている.

（4）人材の養成（研修）

（1）国際協力事業団から受託の「集団IIリモート・ センシング技術コースの研修」 ESCAP 諸国より 10 名 (各国 1 名) の研修参加者に対して斯界の権威 を講師陣に仰いで技術研修（講義，見学，実習等を 含む)を行うむのである. 54 年度の研修は 54 年 6 月 14 日より約 8 週間に亘って行われ, 参加国はアフ ガニスタン, バングラデッシュ, インド, インドネ シア, マレーシア, ネパール, フィリッピン, シン ガポール，スリランカ，タイの10カ国であった.

(ロ）科学技術庁から受託の「リモート・センシング 解析技術者の研修」国立研究機関等のリモート・ センシング活動に従事しているあの, または将来従 事すると思われる技術者（54 年度は 23 名）に対し て, 解析理論㧍よび解析装置操作仼関する知識を与 え, デー夕解析・利用に必要な技術を習得させるこ とを目的に研修を行い, リモート・センシング活動 の一層の発展に資するものである。

（5）普及啓発

（イ）財団の機関誌 RESTEC 3 号, 4 号を刊行し広く 一般に配布した. 
（ロ）第 3 回リモート・センシング シンポジウムおよび国際セミナー を科学技術庁, 宇宙開発事業団, 経済団体連合会・宇宙開発推進会 議と協力して開催した. シンポジ ウムは 54 年 7 月に，国際セミナ 一は 54 年 11 月汇行った。

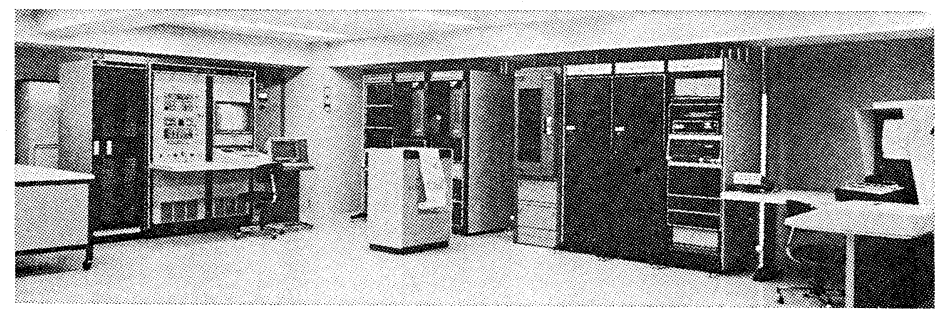

（ハ）その他いろいろな広報活動とかパンフレットの 作成配布も行った。

\section{2. 研 究 部}

(1) 科学技術庁から受託の「デー夕解析研究」 この研究はランドサットデータの有用性を向上する ための手法を開発する研究で, 同一地域を異なった時 期に観測したデータの観測条件（日射の強さ，大気の 減衰特性等）の違いを補正する手法, 画像のサンプリ ング手法の違いの評価等の研究を行った.

（2）宇宙開発事業団加受託の「地上基準点の選定」 この研究はランドサット MSS 画像を幾何学的に精 密補正処理を行うのに必要な地上基準点（ハイウェー の交差点, 空港等 MSS 画像上で識別容易な点) を選 定する仕事である.1シーンについて十数点, 日本全 土をカバーする約 50 シーンについて総計約 600 点を 選定した。

（3）宇宙開発事業団から受託の「ランドサットデータ の解析研究」

ランドサットデータの受信, 記録, 処理業務に関す る技術的問題点について解析研究を行うむので, 精密 補正処理データの幾何補正精度の評価，ハイゲインモ ードの画像の $S / N$ 改善度の評俩, リサンプリング方 法の分類結果への影響の評価等の研究を行った.

（4）農業技術研究所加ら受託の「耕草林地の一次生産 力の地理的分布の評価に関する調査」

太陽エネルギーを農林業に効率的に利用しようとす る農林水産省の総合研究「グリーン・エナージー計 画」の一環として行われたもので, 自然エネルギー資 源としての植物の一次生産力の地理的分布を, リモー ト・センシング技術により把握する手法を開発する研 究である. ランドサットから稻の作付面積, および生 産力を推定する手法, 森林の樹種分類, 材積量, 成長 量を推定する手法の開発研究を行った.

（5）国立防災科学技術センターから受託の「ランドサ ットデータによる1979 年御岳山噴出物調查」

1979 年 10 月 28 日に突如御岳山が噴火したが，元の 前後 10 月 23 日と 11 月 1 日に同地域を観測したラン ドサットデータを使って降圧領域を検討する研究で, 噴火前後のランドサット画像を重悋合せて降灰領域の

分光反射特性を調查し, 降灰領域をディジタル的に抽 出する研究を行った.

\section{3. 技術部}

1972 年に米国が人工衛星ランドサット 1 号を打上 げ，1975 年に 2 号，1978 年に 3 号を打上げ，現在 2 号, 3 号が観測に使われている. 1979 年 1 月, 埼玉県 鳩山村に宇宙開発事業団の地上受信局方開設し, 受信 を開始してから日本および周辺のデータがランドサッ トより直接受信できるとととなった。 てれらのデータ の一般配布（国内一般ユーザーおよび海外ユーザーに 対する有償配布）を行っている. 54 年度は写真 1, 204 枚 CCT 108 シーンの配布を行った。 また, 米国の EROS・データセンターより入手して配布したデータ が写真で 222 枚 CCT シーンで 23 シーンの実績であ った。

\section{3. 解 析 装 置}

財団設立時三井物産・三菱商事両社の援助により米国 GE - IMAGE-100 Interactive Multispectral Image Analysis System \& BENDIX M-DAS Multispectral Data Analysis System の 2 台の解析装置を取得し上記 研修業務や各種研究調查使用している.

\section{4. むす び}

リモート・センシングはまだまだ一般の人々に知られ ていないので, 国際セミナー, シンポジウムの開催への 協力, 機関誌 “RESTEC” の刊行等の普及啓発に今後之 も注力していくつもりである. 特に昨今, 地球資源の問 題が大きくクローズアップされている時でああり, リモ 一トセンシング技術による地球資源の探査, 観測, 管理が 大きくとりあげられている.アメリカではランドサット D, D'を1982〜83 年頃に，ヨーロッパではフランスが SPOT 衛星を 1984 年付上打将る予定で計面が進められ ており, 人工衛星から得られるリモート・センシングデ 一夕の実用化に向っての計画が着々と進められている. 日本に扔いてむ, 海洋観測衛星や地球資源衛星 (ERS) を欧米に伍して独自の技術により打上げを計画してい る. 財団はこれらの計画の一端を荷なって事業内容の充 実と拡大を図っている. 大方のご理解とで支援を和願い する. 